\title{
Preface and acknowledgments to the first edition
}

In 2001 I received an invitation from Gideon Rosenbluth to collaborate on a book. Gideon had supervised my Ph.D. dissertation in the later 1960s and over the years we had kept in touch. The chance to work with Gideon again came just at the right time. I had just completed my term as the Dean of the Faculty of Environmental Studies at York University, having worked for many years as a consultant and public servant, and I was eager to get my teeth into something truly academic. We agreed on the general outline of what we wanted to do and produced three papers on managing without growth, out of which this book developed. Gideon let me write the book on my own but he read significant parts of it in draft and provided his customary insightful and critical comments. I am greatly indebted to him for his lasting guidance so generously given all those years ago at the University of British Columbia and for his continuing interest, advice and support that was so valuable in writing this book.

Another economist whose influence on me has been considerable is Herman Daly, the leading contributor to and exponent of ecological economics. I have known Herman since the mid-1970s when he republished a paper of mine in his edited book Economics, Ecology, Ethics. Essays Toward a Steady-State Economy. Herman has helped shape my view of economies as subsystems of the biosphere and his influence on my thinking about these matters is substantial.

The main argument I make in this book is that we in the rich countries can and should manage without economic growth so that people living in poorer countries can enjoy the benefits of economic growth where it really makes a difference to their well-being. At the very least, we should demote economic growth from its position atop the hierarchy of policy objectives in rich countries and concentrate our efforts on more specific welfareenhancing policy objectives. I think it is implausible that the biosphere can support the nine billion people, more or less, who are expected to be on Earth by mid-century at a standard of living remotely like that of current day North Americans. In any case, there is plenty of evidence to show that economic growth is doing very little to increase the happiness of most of us in rich countries. So as Clive Spash writes, our economies should be 
'smaller by design rather than smaller by disaster' (Spash 2007), which inspired the subtitle of this book.

In the book I employ some simulation models to help illustrate specific parts of this argument and in particular to explore the possibility for Canada to meet important economic, social and environmental objectives without relying on economic growth. I am very grateful to Matthias Ruth for introducing me to the Stella programming language which is designed for building models based on systems dynamics. I use Stella in all of the models described in the book. I began to learn Stella while on sabbatical leave at Keele University (UK) in 2001 where I discussed some of my early thinking on the issues dealt with in the book with John Proops.

I owe much to colleagues in the Toronto area who have helped me in various ways: Peter Timmerman who read several chapters in draft and helped me improve the exposition of my ideas, economists George Fallis and John Grant who encouraged me to pursue a topic which is anathema to most members of our shared profession, and my long-time friend, environmental scientist Ed Hanna with whom I have had many discussions about the relationship between the economy and the environment.

It is doubtful whether I could have written this book without the help of my students. Over a period of three months in early 2007 I met with a group of six MES students at York University to review and discuss early drafts of most parts of the book: Howie Chong, Ed Crummey, Katie Fotheringham, Roberto Garcia, Andreas Link and Nathan Okonta. The tables were turned and they critiqued my work, often with gusto. It was a terrific stimulus to produce something in writing on a weekly basis and by the start of the summer of 2007 I had drafted substantial portions of the book.

I owe a special thanks to Ed Crummey who worked as my research assistant for six months and helped me in so many ways. He tracked down information, reviewed literature, estimated equations and checked the model in which they are incorporated, helped with the bibliography, read drafts and wrote notes on issues such as technology assessment, the capital tax and the reports of the IPCC on which parts of the book are based. Ed has a very bright future in ecological economics.

Another student to whom I am indebted is Tatiana Koveshnikova who worked with me on a systems dynamics model of Hubbert's peak that is used in the book. While there is considerable debate about whether and when the production of conventional oil will peak at the global level there is no doubt that it did so long ago in the United States. Our interest is in how the USA will reduce its dependence on imported oil, which is a matter of great concern if world peak oil materializes within the next decade as more and more commentators are predicting. Tatiana has been a very 
conscientious co-researcher on this question and contributed much to the design and construction of our Hubbert's peak model.

I have drawn extensively on publicly available information from Statistics Canada, Canada's first class statistical agency. By providing easy electronic access to vast quantities of well-organized and well-documented data, Statistics Canada makes possible an incredible range of research in the social sciences in Canada. What impressed me even more than the data was the excellent technical support that Statistics Canada provides. On many occasions Ed or I would call a member of staff at Statistics Canada if we could not find what we were looking for or if we required further explanation. The response from staff at Statistics Canada was always professional in the very best sense of the term, and was matched only by the extraordinarily fine service we received from Walter Giesbrecht, the data librarian at York University.

In developing my ideas I had the opportunity to present papers at many seminars and conferences where I received helpful comments: the Faculty of Environmental Studies at York University (2004), the University of Newcastle in Australia (2004) at the invitation of Philip Lawn which was the first time that I aired the main argument and analysis publicly, the biennial meeting of CANSEE (2005), as a guest in a course run by Doug Worts at George Brown College (2005), the Progressive Economics Forum at the annual meeting of the Canadian Economics Association (2005), and at a conference at the University of Ontario Institute of Technology (2006).

Above all I thank my wife Maria for her confidence in me and in her belief that what I was writing about really does matter. She has encouraged me continually and provided a home thoroughly congenial for work of this kind, even while writing a book of her own. It is to her, our daughters Carmen and Marisa, their husbands Mischa and Marc, our grandchildren Rio, Sacha and Gryffin, and their great grandmother Ruth that I dedicate this book. 